\title{
Enhancing Bioenergetics Models to Account for Dynamic Changes in Fish Body Composition and Energy Density
}

\author{
JAMES E. BRECK* \\ Institute for Fisheries Research, Michigan Department of Natural Resources; and \\ University of Michigan, 1109 North University Avenue, Ann Arbor, Michigan 48109-1084, USA
}

\begin{abstract}
Fish proximate composition and energy density can influence growth, survival, and reproduction, so it is important to develop models to understand the patterns and predict dynamic changes. This paper presents three such models. Model 1 describes the general pattern of changes in lipid, protein, ash, and energy density that occur with changes in water content. The key assumption this model is that there is a fixed amount of water associated with each gram of protein and a much smaller fixed amount of water associated with each gram of lipid. In combination with a mass balance constraint, this explains the commonly observed linear relationship between the fraction lipid and the fraction water. Because energy density varies in direct proportion to the fractions lipid and protein, the linear relationship between body composition and fraction water makes energy density also a linear function of the fraction water. The model is fitted to data for lake trout Salvelinus namaycush and coho salmon Oncorhynchus kisutch for a limited range in wet weight. Model 2 describes the pattern of proximate composition and energy density that occurs with variation in body size. A strong pattern was found between the mass of water and the mass of protein, suggesting strict control of body water. The model is fitted to data for common carp Cyprinus carpio and bluegill Lepomis macrochirus. This analysis shows that the relationship between body composition, energy density, and fraction water is expected to vary with body size because both the water : protein ratio and the fraction ash change with body size. Model 3 demonstrates how this approach can be used to predict changes in fish body composition and energy density during starvation, as might be done with a bioenergetics model. This model is fitted to data from a starvation experiment involving largemouth bass Micropterus salmoides.
\end{abstract}

A model for fish proximate composition and energy density would improve understanding of observed patterns in fish body composition data and enhance bioenergetics models of fish growth. A model for proximate composition could help explain two common patterns related to percent lipid and energy density, which are linearly related to percent water (Love 1970; Elliott 1976; Rottiers and Tucker 1982; Hartman and Brandt 1995; Iverson et al. 2002). Fish body composition typically changes in response to changes in ration level (Gerking 1955; Elliott 1976; Huisman et al. 1979; Weatherley and Gill 1983), including starvation (Savitz 1971; Niimi 1972). Body composition also changes during ontogeny (Tarby 1977; Henderson and Ward 1978; Wuenschel et al. 2006), so several aspects of the energetics of fish growth are related to body composition. The stored energy available to a fish, as reflected in its body composition and energy density, also influences its survival and reproduction. A model for body composition could help in understanding many aspects of fish biology and ecology.

For bioenergetics models of fish growth, the energy

* E-mail: breck@umich.edu

Received October 3, 2005; accepted February 28, 2007 Published online February 14, 2008 densities of a fish and its prey are among the most influential factors affecting predicted consumption and growth (Hartman and Brandt 1995). Although the energy density of fish and prey were not explicitly included in the sensitivity analyses of Kitchell et al. (1977) or Bartell et al. (1986), those analyses indicated that factors proportional to consumption (e.g., the energy value of food) have the greatest influence on predicted fish growth.

Fish energy density can influence survival and reproduction as well as growth. Energy level in late fall can affect overwinter survival (Oliver et al. 1979; Shuter et al. 1980; Thompson et al. 1991). Energy level at the end of winter can influence the timing of reproduction. Cargnelli and Gross (1997) have shown that larger male bluegills Lepomis macrochirus emerge from winter in better condition and with higher levels of lipid than smaller males. They note that this may explain why larger individuals of both sexes tend to breed earlier than smaller individuals in several sunfish species (Ridgway et al. 1991; Danylchuk and Fox 1994). Females in better condition, with greater energy stores, generally have higher fecundity (Lam 1983; Breck 1996). In some fish species, adults may skip 1 or more years of reproduction to attain sufficient energy reserves (e.g., Arctic char Salvelinus alpinus and 
several species of sturgeon; Dutil 1986; Doroshov 1985).

Fish energy density changes in response to recent feeding history. Energy density declines during starvation (Savitz 1971; Niimi 1972; Elliott 1976), including starvation overwinter (Oliver et al. 1979), and increases as daily ration increases (Brett et al. 1969; Niimi and Beamish 1974; Elliott 1976; Tyler and Dunn 1976; Heidinger and Crawford 1977; Weatherley and Gill 1983; Brown and Murphy 1991). The energy density of yellow perch Perca flavescens increased following a reduction in the density of competing white suckers Catostomus commersonii, which apparently made more food available to yellow perch (Hayes and Taylor 1994). Because energy density is so closely linked to growth, changes in the amount of food are expected to lead to changes in energy density as well as growth. In fish models with interacting predators and prey (e.g., Anderson and Ursin 1977; Breck 1993; Rose et al. 1999), food availability to fish changes through time. This suggests the need for a model to predict changes in fish energy density in response to food availability and metabolic demands.

Ontogenetic changes in body composition are commonly observed. Fish larvae tend to have higher percentage water content than juveniles and adults (Tarby 1977; Henderson and Ward 1978; Machiels and Henken 1986, 1987; Wuenschel et al. 2006). Ash content is higher in larger fish (McComish 1974; Niimi 1974; Focken and Becker 1993; Barziza and Gatlin 2000). For many species, percent lipid tends to increase as body size increases (Elliott 1976; Rottiers and Tucker 1982; Van Pelt et al. 1997; Pothoven et al. 2006; Wuenschel et al. 2006; but see Craig 1977; Anthony et al. 2000). Because energy density is so closely linked to growth, changes in nominal energy density across life stages should lead to ontogenetic differences in the growth response.

Various approaches to specifying the energy density of fish and prey have been used in typical applications of bioenergetics models, in which the pattern of fish growth through time is known in advance; these models are used to calculate fish consumption of prey. For example, the bioenergetics models of Kitchell et al. (1977), Rice et al. (1983), Stewart et al. (1983), Stewart and Ibarra (1991), and Hewett and Johnson (1992) predict consumption for a single population at a time, given initial and final fish sizes. For each group of fish modeled, the energy density is assumed to be constant through the year (Kitchell et al. 1977; Breck 1993; Rose et al. 1999), changing as a function of fish body size (Stewart et al. 1983) or changing seasonally in a specified and predetermined pattern (Hewett and Johnson 1992; Hartman and Brandt 1995). However, these approaches are less applicable in dynamic models of predators and prey because prey density can vary during simulation runs and from run to run, so the seasonal pattern of predator ration, which affects energy density and growth, is not known in advance.

It would be useful for a fish growth model to be able to compute the body condition or relative weight of predators and prey so that the model could be used to determine expected responses under alternative scenarios (Rice et al. 1983; From and Rasmussen 1984; Van Winkle et al. 1997). Examination of the average body condition of predators and prey has been proposed as a means of assessing the predator-prey status of lakes and ponds (Wege and Anderson 1978; Anderson and Gutreuter 1983; Murphy et al. 1991; Liao et al. 1995). Some studies have found relative weight (or condition factor) to be positively correlated with energy density (Brown and Murphy 1991; Jonas et al. 1996) and growth (Willis et al. 1991) and negatively correlated with percent water (McComish 1974). Other studies have found no correlation between relative weight and growth (Liao et al. 1995) or lipid level (Simpkins et al. 2003). A useful step toward predicting relative weight and reconciling differences among studies would be a model that could explain patterns of body composition and how they change with starvation and growth.

In summary, there are several reasons for developing a model for fish proximate composition and energy density to enhance bioenergetics models. Such a model would help in accounting for several important effects on fish growth, reproduction, and survival. First, predicted growth in bioenergetics models is very sensitive to energy density of fish and their food. Second, energy reserves influence survival and reproduction. Third, energy density can change in response to recent feeding history. Fourth, energy density changes with ontogeny. Fifth, a changing pattern of energy density would be more appropriate for a simulation model in which food availability can change dynamically. A model for body composition and energy density would be a useful addition to a bioenergetics model.

The purpose of this paper is to describe two models relating the proximate body composition and energy density of fish to the fraction water. The approach is used in a third model for simulating the changes in body composition and energy density during starvation. The first model can explain two common observations related to the body composition of fish during starvation and growth: (1) the linear relationship between percent lipid and percent water (e.g., Love 1970; Rottiers and Tucker 1982) and (2) the linear relationship between energy density and percent water (e.g., Rottiers and Tucker 1982; Hartman and Brandt 
1995; Anthony et al. 2000). The second model describes the pattern of body composition and energy with variation in body size and percent water. The third model predicts changes in wet weight, relative weight, body composition (lipid, protein, ash, water), and energy density based on the energy used each day during starvation.

\section{Model 1: Basic Patterns of Body Composition and Energy Density}

\section{Description}

Model 1 provides the expected relationships between fraction water and fraction lipid, fraction protein, and energy density based on (1) the energy density of protein and lipid, and (2) information on the amount of water associated with each gram of protein and each gram of lipid in the body. The relationships presented allow the amount of water associated with protein and lipid to be estimated based on empirical data on energy density and fraction water; alternatively, the slope and intercept of the linear regression of energy density on fraction water can be determined if estimates of the amount of water associated with protein and lipid are available. This approach is only appropriate for fish of a similar size. The next model includes additional features to account for the more complicated relationships when there is a wide range in body sizes.

\section{Model Development}

Energy density, usually measured on a wet weight basis $(\mathrm{kJ} / \mathrm{g}$ of wet weight), reflects proximate body composition in terms of lipid, protein, carbohydrate, ash, and water. Assuming that lipid level has been measured using appropriate methods (Randall et al. 1991; Iverson et al. 2001), energy density can be calculated using standard values for the energy value of lipid, protein, and carbohydrate (Elliott 1976; Brett and Groves 1979; Brett 1995). The amount of carbohydrate in fish is usually negligible $(<0.14 \%$; Craig 1977 ; Craig et al. 1978), so it will be assumed to be zero in this analysis. Brett and Groves (1979) mention a value of $39.5 \mathrm{~kJ} / \mathrm{g}$ for lipids synthesized by fish; they also note that highly saturated fats in fish have a lower heat of combustion $(36.2 \mathrm{~kJ} / \mathrm{g})$ than saturated animal fats $(39.5 \mathrm{~kJ} / \mathrm{g})$, and they recommend the fish-specific value. Craig et al. (1978) extracted lipid from European perch (also known as Eurasian perch) Perca fluviatilis and measured the heat of combustion as $35.5 \pm 4.9 \mathrm{~kJ} /$ g (95\% confidence interval $[\mathrm{CI}]$ around the mean). More recently, Brett (1995) noted that literature values for fish lipid range from 34.7 to $39.3 \mathrm{~kJ} / \mathrm{g}$. In his analysis of salmon energetics, Brett (1995) used an average value of $36.4 \mathrm{~kJ} / \mathrm{g}$. In my analysis I used
Brett's (1995) value of $36.4 \mathrm{~kJ} / \mathrm{g}$ of lipid. The recommended energy value of fish protein, as measured by bomb calorimetry, is $23.6 \mathrm{~kJ} / \mathrm{g}$ of protein (Brett and Groves 1979). However, for the later discussion of response to starvation, note that the metabolizable energy value of protein to fish is only $20.1 \mathrm{~kJ} / \mathrm{g}$ because most fish break down protein into ammonia as a nitrogenous waste. Therefore, less energy is obtained than when the protein is completely oxidized in a bomb calorimeter (Brett and Groves 1979). In this analysis I used $23.6 \mathrm{~kJ} / \mathrm{g}$ protein when calculating the energy content of fish to compare with data from bomb calorimetry and $20.1 \mathrm{~kJ} / \mathrm{g}$ protein when calculating the loss in protein from catabolism during starvation.

Assuming that the amount of carbohydrate is negligible, fish body composition can be categorized as lipid, protein, water, and ash. As fractions of total wet weight, these components must sum to 1 ; that is, there is the following mass balance constraint:

$$
f+p+h+a=1,
$$

where $f$ is the fraction lipid (fat), $p$ the fraction protein, $h$ the fraction water, and $a$ the fraction ash. Table 1 contains a list of symbols and their definitions for all variables and parameters used in the models.

Fish energy density $(d ; \mathrm{kJ} / \mathrm{g})$ can be computed from the fraction lipid and the fraction protein by using the energy density of lipid $\left(D_{f} ; \mathrm{kJ} / \mathrm{g}\right.$ of lipid $)$ and the energy density of protein $\left(D_{p} ; \mathrm{kJ} / \mathrm{g}\right.$ of protein). Because neither water nor ash contributes to energy content,

$$
d=f D_{f}+p D_{p} .
$$

It would be helpful to link equations (1) and (2) to determine the expected relationship between energy density and fraction water. To do this, an additional relationship is needed. The needed relationship can be derived from the observation that body water is primarily associated with protein, and a small amount of water is associated with lipid. The key assumption for model 1 is that there is a fixed amount of water $(y)$ associated with each gram of protein and a smaller fixed amount of water $(z)$ associated with each gram of lipid. Gerking (1955, citing Newburgh et al. 1945) and Schmidt-Nielsen (1975:120) note that about $0.1 \mathrm{~g}$ of water is associated with a gram of adipose tissue $(z$ is about 0.1 ), and about $3 \mathrm{~g}$ of water is associated with a gram of protein ( $y$ is about 3). Jobling (1994:147) notes that, in a growing fish, deposition of $1 \mathrm{~g}$ lipid "leads to a weight increase of $1 \mathrm{~g}$," suggesting that very little water is added and that $z$ must be much smaller than 1 , whereas deposition of $1 \mathrm{~g}$ protein "leads to the deposition of 3-4 g water," suggesting that $y$ is about 
TABLE 1.-Variables and parameters used in three models for fish body composition and energy density.

\begin{tabular}{llrr}
\hline & & \multicolumn{2}{c}{ First appearance } \\
\cline { 3 - 4 } Symbol & \multicolumn{1}{c}{ Definition } & Equation & Model \\
\hline \multirow{2}{*}{$\alpha$} & Fraction of protein energy usable during starvation & 24 & 3 \\
$a$ & Fraction ash $(=A / W)$ & 1 & 1 \\
$a_{A}$ & Intercept in $\log _{e}(A)=a_{A}+b_{A} \log _{e}(W)$ & 15 & 2 \\
$a_{d}$ & Intercept in $d=a_{d}+b_{d} h$ & 9 & 1 \\
$a_{H}$ & Intercept in $\log _{e}(H)=a_{H}+b_{H} \log _{e}(P)$ & 25 & 3 \\
$a_{h W}$ & Intercept in $d=a_{h W}+b_{h W} h+c_{h W} \log _{e}(W)$ & 30 & 2 \\
$a_{P}$ & Intercept in $\log _{e}(P)=a_{P}+b_{P} \log _{e}(H)$ & 13 & 2 \\
$A$ & Ash mass $(\mathrm{g})$ & 15 & 2 \\
$b_{A}$ & Slope in $\log _{e}(A)=a_{A}+b_{A} \log _{e}(W)$ & 15 & 2 \\
$b_{d}$ & Slope in $d=a_{d}+b_{d} h$ & 9 & 1 \\
$b_{H}$ & Slope in $\log _{e}(H)=a_{H}+b_{H} \log _{e}(P)$ & 25 & 3 \\
$b_{h W}$ & Slope in $d=a_{h W}+b_{h W} h+c_{h W} \log _{e}(W)$ & 30 & 2 \\
$b_{P}$ & Slope in $\log _{e}(P)=a_{P}+b_{P} \log _{e}(H)$ & 13 & 2 \\
$c_{h W}$ & Slope in $d=a_{h W}+b_{h W} h+c_{h W} \log _{e}(W)$ & 30 & 2 \\
$d$ & Fish energy density $(\mathrm{kJ} / \mathrm{g})$ & 2 & 1 \\
$D_{f}$ & Energy density of lipid $(\mathrm{kJ} / \mathrm{g})$ & 2 & 1 \\
$D_{p}$ & Energy density of protein $(\mathrm{kJ} / \mathrm{g})$ & 2 & 1 \\
$E$ & Total body energy $(\mathrm{kJ})$ & 21 & 2 \\
$f$ & Fraction lipid $($ fat $)(=F / W)$ & 1 & 1 \\
$F$ & Lipid mass $(\mathrm{g})$ & 19 & 2 \\
$h$ & Fraction water $(=H / W)$ & 1 & 1 \\
$H$ & Water mass $(\mathrm{g})$ & 13 & 2 \\
$p$ & Fraction protein $(=P / W)$ & 1 & 1 \\
$P$ & Protein mass $(\mathrm{g})$ & 13 & 2 \\
$s$ & Fraction of energy coming from $\operatorname{lipid}_{1}$ in starvation & 23 & 3 \\
$W$ & Total fish mass $(\mathrm{g})(=H+P+F+A)$ & 15 & 2 \\
$y$ & Fixed amount of water associated with each g of protein & 3 & 1 \\
$z$ & Fixed amount of water associated with each $\mathrm{g}$ of lipid & 3 & 1 \\
\hline & & & \\
\hline
\end{tabular}

3-4. According to this assumption, the fraction water (h) depends on the fraction protein and the fraction lipid, that is,

$$
h=y p+z f,
$$

where $y$ and $z$ are assumed to be constant.

With this additional relationship, energy density can be expressed in terms of fraction water. First, equation (3) can be rearranged to express $p$ in terms of $h$ and $f$, that is,

$$
p=(h-z f) / y .
$$

This expression for $p$ is then inserted into equation (1). Solving for $f$ leads to an equation for the fraction lipid as a linear and decreasing function of the fraction water. The slope is $-(1+y) /(y-z)$, the intercept is $y(1$ $-a) /(y-z)$, and

$$
f=\frac{y(1-a)-h(1+y)}{(y-z)} .
$$

For the current assumptions, this equation will hold until $f$ declines to zero, which occurs when

$$
h=\frac{y(1-a)}{1+y} .
$$

In a similar way, equations (3) and (1) produce an equation for the fraction protein as a linear and increasing function of the fraction water, namely,

$$
p=\frac{h(1+z)-z(1-a)}{(y-z)} .
$$

For these assumptions, this equation will hold until $f$ declines to zero. For water content higher than the threshold given by equation (5),

$$
p=1-h-a .
$$

When represented graphically, model 1 's relationships for body composition are simple straight lines (Figure 1). Example parameters (estimated from the data discussed below) are given in the caption. The top panel shows cumulative proportions, so the area between successive lines indicates the proportions of lipid, protein, ash, and water plotted against fraction water. The lower panel shows the individual components plotted against fraction water. Fraction ash is assumed to be constant. Note that the slope for fraction protein changes abruptly when lipid reaches zero. Published reports often graph individual components as in Figure 1B, but the general pattern of body composition given by model 1 may be easier to visualize in Figure 1A.

Inserting equations (4) and (6) into equation 
yields the following linear equation for energy density, in which energy density decreases as the fraction water increases:

$$
\begin{aligned}
d= & \left(\frac{1-a}{y-z}\right)\left(y D_{f}-z D_{p}\right) \\
& -h\left[\frac{(1+y) D_{f}-(1+z) D_{p}}{y-z}\right] .
\end{aligned}
$$

Equation (8) indicates that a linear regression of energy density on fraction water is expected to have an intercept $\left(a_{d}\right)$ and slope $\left(b_{d}\right)$ given by the following equations:

$$
\begin{aligned}
& a_{d}=\left(\frac{1-a}{y-z}\right)\left(y D_{f}-z D_{p}\right) \\
& b_{d}=-\left[\frac{(1+y) D_{f}-(1+z) D_{p}}{y-z}\right] .
\end{aligned}
$$

The parameters $y$ and $z$ can be estimated from empirical data on energy density and fraction water. The following equations (derived from equations 9 and 10) determine $y$ and $z$ by using $a_{d}$ and $b_{d}$ from a linear regression of energy density on fraction water along with information on fraction ash and the energy density of lipid and protein. Note that the estimate for $y$ has a linear dependence on the value for $D_{p}$, the estimate for $z$ has a linear dependence on the value for $D_{f}$, and both depend on the value for fraction ash, that is,

$$
\begin{aligned}
& y=\frac{-a_{d}+D_{p}(1-a)}{a_{d}+b_{d}(1-a)} \\
& z=\frac{-a_{d}+D_{f}(1-a)}{a_{d}+b_{d}(1-a)} .
\end{aligned}
$$

\section{Comparison with Data}

The relationships specified by model 1 can be compared with the extensive data collected by Rottiers and Tucker (1982) on the proximate composition and energy density of several Great Lakes fishes. It should first be noted that model 1 is intended to describe the general pattern of proximate composition and energy density with water content. As will be shown below (models 2 and 3), a more complicated pattern appears when there is a wide range of fish sizes. For this reason, the comparison of model 1 with data will be restricted to fish with weights differing by less than a factor of three.

Rottiers and Tucker (1982) reported the body composition (percent water, percent lipid, percent ash, and percent protein as fat-free dry matter) and energy density for nine fish species found in the Great Lakes. In my comparisons I used 104 samples from
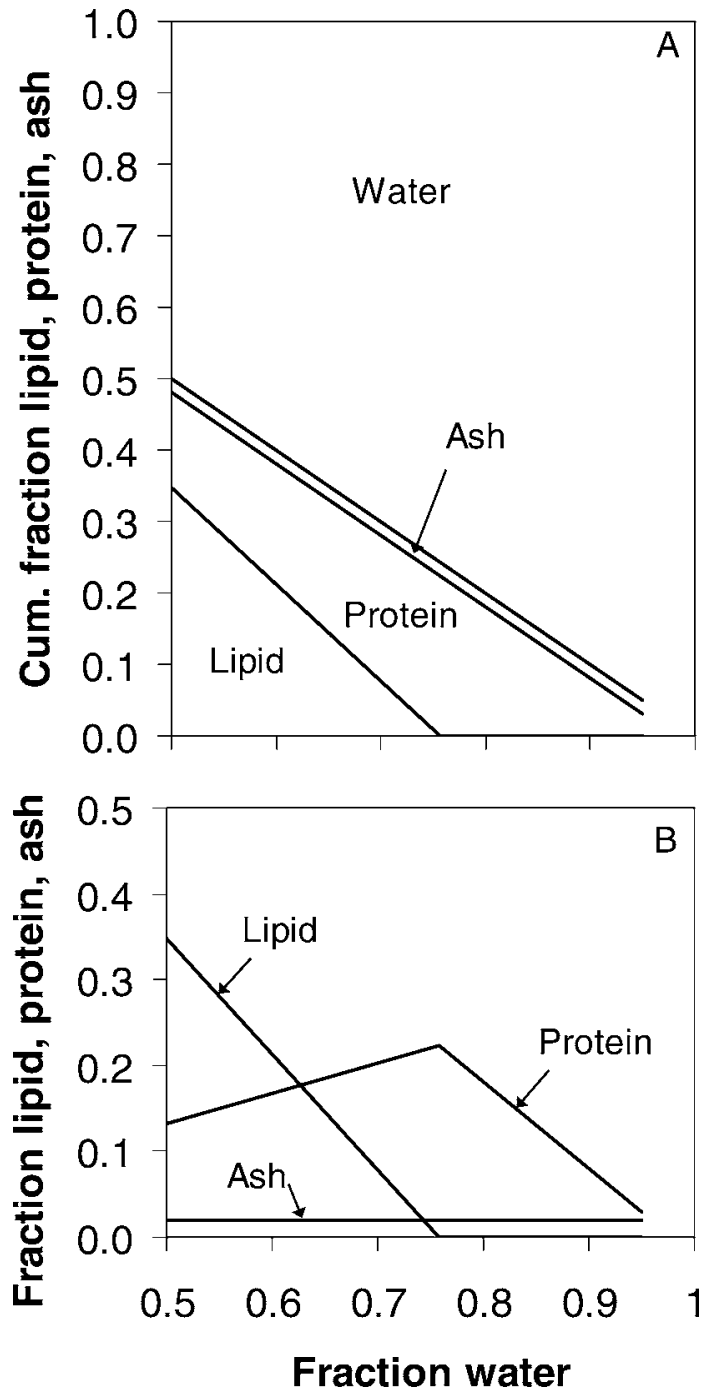

FIGURE 1.-Body composition relationships for fish as specified by model 1 . In this example, the fraction ash $=0.02$, $y=3.4 \mathrm{~g}$ of water per gram of protein, and $z=0.16 \mathrm{~g}$ of water per gram of lipid (values estimated from the data in Figure 2). Panel (A) shows the cumulative proportions (so that the areas between successive lines indicate the proportions of lipid, protein, ash, and the rest is water) and Panel (B) the individual components plotted against fraction water (note the abrupt change in slope for the fraction protein when the fraction lipid reaches zero).

lake trout Salvelinus namaycush and coho salmon Oncorhynchus kisutch with weights ranging from a maximum of $5,178 \mathrm{~g}$ down to a minimum of $1,780 \mathrm{~g}$ (one-third the maximum weight). The sample sizes for other species were much smaller (1-17 samples). I omitted three samples where the sum of the reported percentages differed from $100 \%$ by more than $5 \%$. 
A regression of energy density on fraction water for lake trout and coho salmon produced an intercept of $37.89 \mathrm{~kJ} / \mathrm{g}(95 \% \mathrm{CI}: 36.76-39.02)$ and a slope of -42.94 (95\% CI: -44.68 to $-41.19 ; N=104, r^{2}=0.96$ ). These fish had an average fraction ash of 0.0182 ( $\mathrm{SE}=$ $\pm 0.0003, N=104)$. Use of the regression slope and intercept in equation (11) results in an estimated value of $y$ of $3.45 \mathrm{~g}$ of water per gram of protein. Note that this estimate of $y$ depends on the value for energy density of protein $(23.6 \mathrm{~kJ} / \mathrm{g})$. In equation (12) the estimated value for $z$ depends linearly on the energy density of lipid. Using Brett's (1995) value of $36.4 \mathrm{~kJ} / \mathrm{g}$ lipid produces the value of $z=0.505 \mathrm{~g}$ of water per gram of lipid. A value of $38.6 \mathrm{~kJ} / \mathrm{g}$ would result in $z=0$.

Model 1 makes joint predictions about the relationship of water content to energy density, fraction lipid, and fraction protein. Therefore, estimates of $y$ and $z$ should be simultaneously determined from multiple relationships, not just from a single regression. A weighting factor was used to combine the sum of squared residuals for water content versus energy density and for water content versus lipid content. Data for fraction water versus fraction protein were not used in this estimation because of the strong inverse correlation between fraction protein and fraction lipid at a given level of fraction water: from equation (1), $p=$ $1-f-a-h$. I used the mean value of $a=0.0182$ (SE $= \pm 0.0003)$ as a constant for the $N=104$ fish samples. Using the Minerr function (Mathcad software), I estimated the values of $y$ and $z$ or $y, z$, and $D_{f}$ that minimized the weighted sum of squared residuals for the energy density and lipid data.

When two parameters were jointly fitted to the energy density and lipid data, the estimated value for $y$ was $3.437 \mathrm{~g}$ water/g protein, and the estimated value for $z$ was $0.156 \mathrm{~g}$ water/g lipid. When three parameters were jointly fitted, the estimate for $y$ was the same, the estimate for $z$ was nearly the same $(0.153 \mathrm{~g}$ water/g lipid), and the estimate for the energy density of fish lipid was $37.937 \mathrm{~kJ} / \mathrm{g}$. These values for $y$ and $z$ are quite consistent with the general observations reported by Gerking (1955), Schmidt-Nielsen (1975), and Jobling (1994). The value for energy density of fish lipid is well within the range given by Brett (1995). It is encouraging, given observed water content and the mean value for fraction ash, that two (or three) fitted parameters can give such good joint estimates for energy density, lipid level, and protein level (Figure 2).

\section{Model 2: Variation with Body Size}

\section{Description}

The pattern of proximate composition in fish can appear more complicated when the analysis includes a
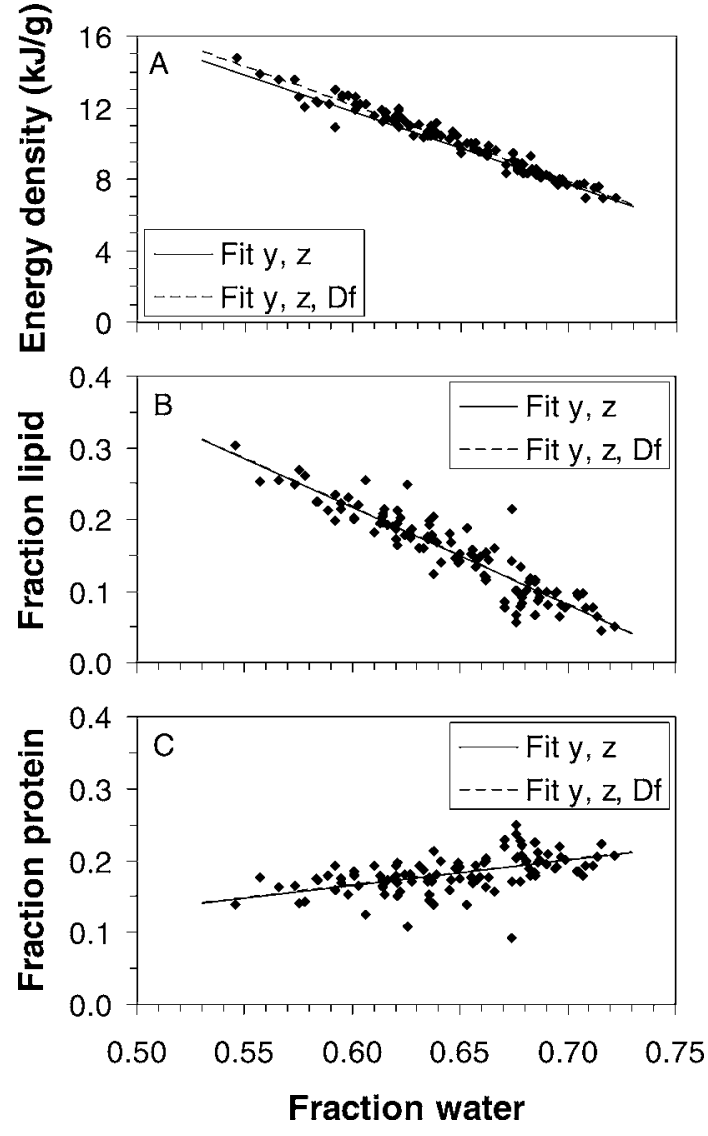

FIGURE 2.-The relationships predicted by model 1 for fraction water and (A) energy density, (B) fraction lipid, and (C) fraction protein. The data points are measured values from Rottiers and Tucker (1982) for 104 lake trout and coho salmon with body weights ranging from 1,780 to $5,178 \mathrm{~g}$. The parameters were estimated jointly from the data shown in panels (A) and (B) and then used to predict the values in panels (A), (B), and (C). The solid lines represent predictions with two estimated parameters: $y=3.437 \mathrm{~g}$ of water per gram of protein and $z=0.156 \mathrm{~g}$ of water per gram of lipid (the energy density of lipid $\left[D_{f}\right]$ was held constant at $36.4 \mathrm{~kJ} / \mathrm{g}$ ). The dashed lines represent predictions with three estimated parameters: $y=3.437 \mathrm{~g}$ of water per gram of protein, $z=0.153$ g of water per gram of lipid, and $D_{f}=37.9 \mathrm{~kJ} / \mathrm{g}$. In panels (B) and $(\mathrm{C})$ the solid and dashed lines virtually overlap. Other parameters are as follows: fraction ash $=0.0182$ and the energy density of protein $\left[D_{p}\right]=23.6 \mathrm{~kJ} / \mathrm{g}$.

large range in body sizes. Model 2 provides the expected relationships between water, protein, ash, lipid, and energy density for fish of different sizes, as a function of wet weight and fraction water. The model is based on (1) the strong relationship between the amount of water and the amount of protein in the body, (2) the strong relationship between the amount of ash and length or weight, (3) estimating the amount of 
lipid by subtraction, so that the components sum to the specified wet weight, and (4) as in model 1, the energy value of lipid and protein. These relationships produce a different pattern than model 1 when fish of different sizes are included in the same analysis, but produce a very similar (but not identical) pattern when all fish are of the same weight. This approach is extended in model 3 to deal with changes in proximate composition during starvation.

\section{Model Development}

Water and protein.-In model 1, I assumed that a fixed amount of water is associated with each gram of protein. In model 2 this assumption is modified. As shown below, the amount of water per gram of protein changes systematically with the total amount of protein in the body. This means that fraction water is expected to change with body size. Water content is also expected to vary with condition or level of starvation (see model 3).

In attempting to model the body composition data of Huisman et al. (1979) for common carp Cyprinus carpio, I found a very strong relationship $\left(r^{2}=0.999\right)$ between the logarithm of protein $(\mathrm{g})$ and the logarithm of water, namely,

$$
\log _{e}(P)=a_{P}+b_{P} \cdot \log _{e}(H) .
$$

For fish of a given weight and fraction water, the grams of water can easily be calculated as $H=h W$, so the following equation (obtained by exponentiating both sides of equation 13) can be used to estimate the grams of protein as a function of weight and fraction water for that fish:

$$
P(W, h)=\exp \left[a_{P}+b_{P} \cdot \log _{e}(h W)\right] .
$$

Dividing both sides by $W$ yields the predicted fraction protein as a function of weight and fraction water, that is,

$p(W, h)=\exp \left[a_{P}+b_{P} \cdot \log _{e}(h)+\left(b_{P}-1\right) \cdot \log _{e}(W)\right]$.

Ash and body size.-Ash content increases allometrically with fish body size (McComish 1974; Niimi 1974; Elliott 1976; Peters 1983; Focken and Becker 1993; Barziza and Gatlin 2000). McComish (1974) and Barziza and Gatlin (2000) found a stronger relationship of ash with body length than wet weight, as would be expected for a body variable more closely related to body structure (length) than to structure plus reserves (weight; Broekhuizen et al. 1994). If length is not known, a relationship can be determined between the logarithm of ash (g) and the logarithm of body weight (g) namely,

$$
\log _{e}(A)=a_{A}+b_{A} \cdot \log _{e}(W) .
$$

Such an equation can be used to predict grams of ash or fraction ash from wet weight (or length, if that information is available) for nonstarving fish, that is,

$$
\begin{aligned}
& A(W)=\exp \left[a_{A}+b_{A} \cdot \log _{e}(W)\right] \\
& a(W)=\exp \left[a_{A}+\left(b_{A}-1\right) \cdot \log _{e}(W)\right] .
\end{aligned}
$$

Lipid.-For fish of a given size, lipid appears to be the most variable of the four body components and the least dependent on the values of the other components. In this model, the amount of lipid is determined by subtraction. The disadvantage of this approach is that all measurement and estimation errors (here, from estimating protein and ash given water and total weight) will be reflected in the estimated value of lipid. This can be problematic, especially when lipid level is so low that it is nearly the same as the amount of ash. The advantage of this approach is that the four mass components will sum to the given weight and the four fractions will sum to 1 , satisfying the massbalance constraint, that is,

$$
\begin{aligned}
& F(W, h)=W-[h W+P(W, h)+A(W)] \\
& f(W, h)=1-[h+p(W, h)+a(W)] .
\end{aligned}
$$

Therefore, given wet weight and fraction water, one can compute the grams of water $(h W)$, protein (equation 14), ash (equation 17), and lipid (equation 19) as well as the fractions of protein (equation 15), ash (equation 18), and lipid (equation 20).

Energy density.-Using weight and fraction water, total body energy $(\mathrm{kJ})$ can be calculated from estimated grams of lipid and protein. Fish energy density $(\mathrm{kJ} / \mathrm{g})$, $d(W, h)=E(W, h) / W$, can be calculated using the fraction lipid and fraction protein determined from the estimated grams of lipid and protein, that is,

$$
\begin{aligned}
& E(W, h)=F(W, h) D_{f}+P(W, h) D_{p} \\
& d(W, h)=f(W, h) D_{f}+p(W, h) D_{p} .
\end{aligned}
$$

If the amount of water per gram of protein varies with the grams of protein (i.e., if $b_{P}$ in equation 13 is significantly different from 1.0 ), then body weight will affect the relationships between fraction water and fraction protein, lipid, and ash, as observed below.

\section{Comparison with Data}

Huisman et al. (1979) carried out growth experiments with common carp of different sizes at two different temperatures $\left(23^{\circ} \mathrm{C}\right.$ and $\left.27^{\circ} \mathrm{C}\right)$ and several ration levels. They reported average energy density and 
percentages of lipid, protein, ash, and water for 30 groups of fish exposed to these various conditions for $28 \mathrm{~d}$. The average value of ash for their samples was $3.3 \%$ of wet weight, notably higher than the ash content of lake trout and coho salmon (1.8\%) measured by Rottiers and Tucker (1982) and somewhat higher than the ash content of brown trout Salmo trutta $(2.6 \%$; Elliott 1976). This data set for common carp involves a large range in body size ( 2.5 orders of magnitude) and thus is useful for evaluating model 2. The smallest group had a mean weight of $2.55 \mathrm{~g}$, and the largest had a mean weight of $953.3 \mathrm{~g}$. This data set also contains higher levels of fraction water (up to $82.1 \%$ ) than the data of Rottiers and Tucker (1982) for lake trout and coho salmon.

For the 30 groups of common carp (Huisman et al. 1979), there was a very strong relationship $\left(r^{2}=0.999\right)$ between the logarithm of protein and the logarithm of water (equation 13): $a_{P}=-1.823$ (95\% CI: -1.870 to $-1.776)$ and $b_{P}=1.066$ (95\% CI: 1.055 to 1.077 ; Figure 3). Reflecting the large size range among the groups, mean values for water and protein ranged from $2.09 \mathrm{~g}$ of water and $0.31 \mathrm{~g}$ of protein for the smallest fish ( $N=750$ fish in the group) to $637.4 \mathrm{~g}$ water and $158.41 \mathrm{~g}$ protein for the largest fish $(N=15)$. This same very strong relationship $\left(r^{2}=0.999\right)$ was also found in the data of McComish (1971) for 100 individual bluegills: $a_{P}=-1.535$ (95\% CI: -1.551 to -1.519$), b_{P}$ $=1.040$ (95\% CI: 1.034 to 1.046; Figure 3). Smaller bluegills (35 mm total length and $0.47 \mathrm{~g}$ wet weight) had $0.35 \mathrm{~g}$ water and $0.07 \mathrm{~g}$ protein, whereas larger bluegills (192 mm and $162.70 \mathrm{~g}$ ) had $111.21 \mathrm{~g}$ water and $29.38 \mathrm{~g}$ protein. A similar strong relationship $\left(r^{2}=\right.$ 0.993 ) was also found in the data of Barziza and Gatlin (2000) for 85 largemouth bass Micropterus salmoides: $a_{P}=-1.342(95 \% \mathrm{CI}:-1.456$ to -1.228$), b_{P}=0.996$ (95\% CI: 0.978 to 1.014). Smaller largemouth bass (235 mm total length, 153.9 grams wet weight) had $148.4 \mathrm{~g}$ water and $37.1 \mathrm{~g}$ protein, whereas the larger ones $(566 \mathrm{~mm}$ and 3,245.3 $\mathrm{g}$ ) had 2,141.9 $\mathrm{g}$ water and $538.7 \mathrm{~g}$ protein. If parameter $b_{P}$ were 1.0 , then water and protein would be in a fixed proportion (as assumed in model 1). Although the value of $b_{P}$ is close to 1.0 , the difference from 1.0 is statistically significant for common carp and bluegill (but not for largemouth bass), as indicated by the confidence intervals. Because $b_{P}$ is greater than 1.0, it means that larger fish (with a larger mass of water) will tend to have relatively more protein and therefore less water per gram protein than smaller fish (with a smaller mass of water).

Because fish length was not reported by Huisman et al. (1979), I determined the relationship between the logarithm of ash and the logarithm of body weight for their data using equation (16). For this data, $a_{A}=$

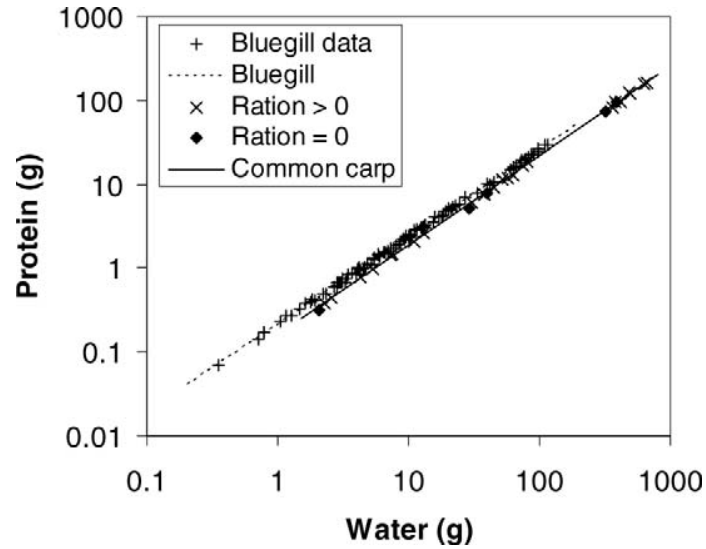

FIGURE 3.- The relationship between water and protein in the data of McComish (1971) for 100 individual bluegills (plus signs) and those of Huisman et al. (1979) for 30 groups of common carp; the carp data include 25 groups fed at various rations greater than zero (times signs) and 5 groups given no food (diamonds). The regression equation is $\log _{e}(P)$ $=a_{p}+b_{p} \cdot \log _{e}(H)$, where $P$ stands for protein and $H$ for water. For bluegills (dotted line), $a_{p}=-1.535$ (95\% confidence interval $[\mathrm{CI}]:-1.551$ to -1.519$), b_{p}=1.040$ (95\% CI: 1.034 1.046 ), and $r^{2}=0.999$. For common carp (solid line), $a_{p}=$ -1.823 (95\% CI: -1.870 to -1.776$), b_{p}=1.066(95 \% \mathrm{CI}$ : $1.055-1.077)$, and $r^{2}=0.999$.

$-3.806(95 \% \mathrm{CI}:-3.970$ to -3.643$)$ and $b_{A}=1.073$ (95\% CI: 1.037-1.109); the relationship was very strong $\left(r^{2}=0.994 ; N=25\right.$ [five starved groups were omitted]).

As indicated above, for both bluegills and common carp smaller fish have more water per gram of protein than larger fish, and smaller fish have relatively less ash than larger fish. These strong relationships, which form the basis for model 2, combine to make expected body composition depend on both body size and fraction water (Figure 4A). For the experiments of Huisman et al. (1979) with common carp, the predicted and observed values are similar for energy density and the fractions of protein, lipid, and ash (Figure 4B, C). Predicted and observed values for the 100 bluegills are also similar (McComish 1971; Figure 5).

Statistical comparisons of predicted and observed values were made for grams of protein, lipid, and ash and for energy density and total body energy. The predicted values result from the equations of model 2 with parameters fit by regression to the data; these are not independent predictions. A major value of the model, indicated in these comparisons, is that it provides an integrated framework to obtain predicted (fitted) values for all body components. Comparisons of predicted and observed values for grams of protein were done using all 30 groups of common carp (Figure 

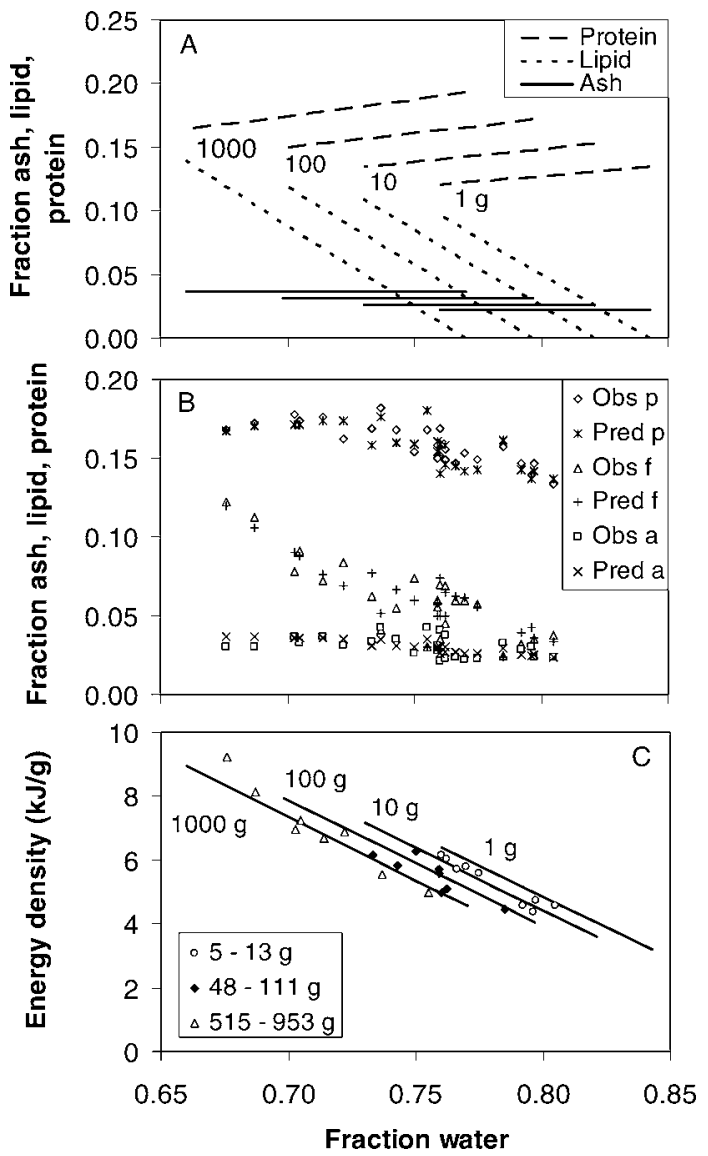

FIGURE 4.-The relationships predicted by model 2 for the fractions of ash (equation 18), lipid (equation 20), protein (equation 15), and energy density (equation 22) and the fraction water for common carp of different weights. Panel (A) shows the predicted effects of fish weight $(1,10,100$, and $1,000 \mathrm{~g}$ ) and fraction water on proximate composition, which are due primarily to the nonlinear relationship between water and protein and secondarily to the allometric relationship between ash and body weight. Panel (B) shows the observed (obs) and predicted (pred) fractions of ash $(a)$, lipid $(f)$, and protein $(p)$ for 25 groups of fed fish (Huisman et al. 1979); 5 groups of starved fish were omitted because model 2 does not account for starvation. Panel (C) shows the effect of fish weight and fraction water on energy density. The lines show the predicted energy densities corresponding to the proximate composition values in panel (A); the symbols indicate the observed energy densities for 25 groups of fed fish disaggregated into three final weight-classes (Huisman et al. 1979).

6A). It was assumed that starvation would not have a large effect on the water-protein relationship. Predicted protein values were computed with equation (14) using the wet weight and fraction water of each group. For a linear regression of $\log$ of predicted grams of protein

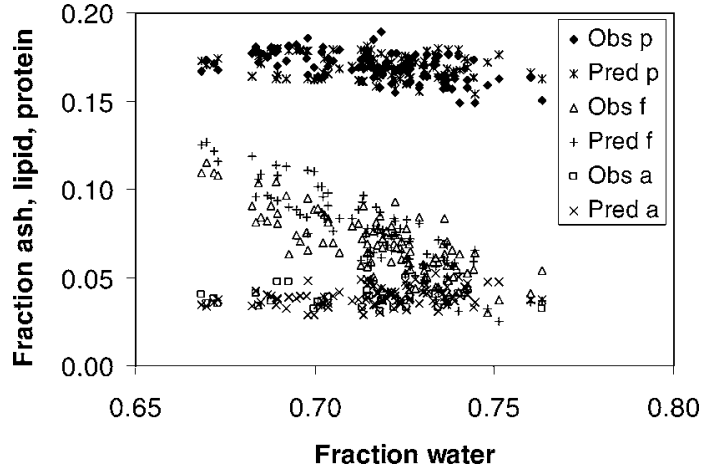

FIGURE 5.-Observed (obs) and predicted (pred) fractions of ash $(a)$, lipid $(f)$, and protein $(p)$ for 100 bluegills (McComish 1971), accounting for fraction water and fish weight. The predictions are from model 2.

on $\log$ of observed g protein, $99.9 \%$ of the variance was explained, the intercept $(0.0015)$ was not significantly different from $0.0(P=0.92 ; 95 \% \mathrm{CI}:-0.030$ to $+0.033)$, and the slope (0.999) was not significantly different from 1.0 (95\% CI: 0.989-1.009).

For lipid, ash, and energy density, comparisons were done using only the 25 nonstarved groups of common carp because model 2 estimates of ash and lipid do not account for starvation. Predicted lipid values were computed with equation (19) using the wet weight and fraction water of each group. For a linear regression of the $\log$ of predicted grams of lipid on the log of observed grams of lipid, $99.5 \%$ of the variance was explained, the intercept (0.059) was not significantly different from $0.0(P=0.10 ; 95 \%$ CI: -0.013 to $+0.131)$, and the slope (0.987) was not significantly different from 1.0 (95\% CI: 0.958-1.016; Figure 6B).

Ash was predicted with equation (17), using the wet weight of each group. For a linear regression of log of predicted grams of ash on log of observed grams of ash, $99.4 \%$ of the variance was explained, the intercept (0.004) was not significantly different from $0.0(P=$ $0.91 ; 95 \%$ CI: -0.067 to +0.075$)$, and the slope $(0.994)$ was not significantly different from 1.0 (95\% CI: 0.961-1.027; Figure 6C). This is a very weak "prediction" because it is based on a $\log -\log$ regression of the same data. Note in Figure 6C that the predicted ash values for the five starved groups are lower than the observed values; this is expected because equation (17) is estimating ash for a nonstarving fish of the same weight.

The predicted values of energy density were computed with equation (22) using the wet weight and fraction water of each group, that is, $D_{f}=36.4 \mathrm{~kJ} / \mathrm{g}$ of lipid and $D_{p}=23.6 \mathrm{~kJ} / \mathrm{g}$ of protein, the same as for Figure 2. For a linear regression of predicted on observed energy density, $92 \%$ of the variance was 
explained; however, the intercept (1.11) was significantly different from $0.0(P=0.001$; $95 \% \mathrm{CI}: 0.50$ $1.73)$, and the slope $(0.82)$ was less than $1.0(95 \% \mathrm{CI}$ : $0.72-0.92)$. The predicted values of energy density tended to be somewhat larger than observed values (Figure 6D). The predicted values were changed slightly by using $D_{f}=35.6 \mathrm{~kJ} / \mathrm{g}$ lipid. This number was obtained by finding the value of $D_{f}$ that minimized the sum of squared differences between predicted and observed values of energy density. However, using this value did not improve the regression of predicted on observed values $\left(r^{2}=0.92\right.$; intercept $=1.16,95 \% \mathrm{CI}=$ $0.55-1.76$; slope $=0.81,95 \% \mathrm{CI}=0.70-0.91)$.

In simulation models involving bioenergetics, it is usually the total body energy of an organism that is of interest (e.g., the total energy content of an individual prey item or of an individual fish before starvation), not just the energy density. Predicted values of total body energy were computed with equation (21) using the wet weight and fraction water of each group of fish, $D_{f}$ $=36.4 \mathrm{~kJ} / \mathrm{g}$ lipid, and $D_{p}=23.6 \mathrm{~kJ} / \mathrm{g}$ protein, the same as for Figure 2 (Figure 6E). For a linear regression of $\log$ of predicted on $\log$ of observed body energy, $99.9 \%$ of the variance was explained, the intercept (0.020) was not significantly different from $0.0(P=$ $0.57 ; 95 \%$ CI: -0.053 to +0.093$)$, and the slope (0.999) was not significantly different from 1.0 (95\% CI: 0.987-1.011).

If additional assumptions are made about the relative use of lipid and protein during starvation, then the methods of model 2 can be used to predict changes in body composition and energy density from estimates of energy use. This approach is developed in the next section.

\section{Model 3: Changes during Starvation}

\section{Description}

Model 3 shows how bioenergetics estimates of energy use during starvation can be used to determine changes in fish energy density and body composition via the approach developed in model 2. More specifically, model 3 allows changes in body energy during starvation to be used to compute changes in body lipid, protein, water, wet weight, and energy density. Changes during growth, which are more complicated because of the need to allocate new biomass between structure and storage, will be considered in a future manuscript.

Whenever an individual's energy expenditures and losses are greater than its energy intake, energy must be obtained from body sources. In this analysis, I use starvation to refer to the situation where net energy intake is negative.
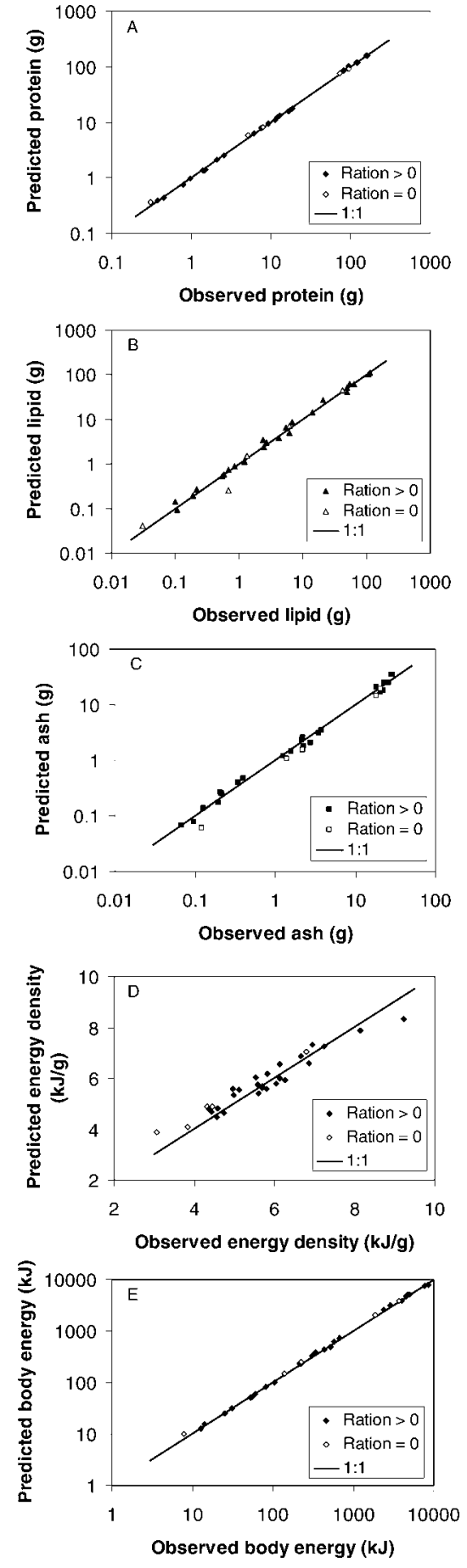

FIGURE 6.-Observed and predicted values of (A) protein, (B) lipid, (C) ash, (D) energy density, and (E) total body energy for 30 groups of common carp (Huisman et al. 1979). The solid symbols denote values for the 25 groups fed at various rations greater than zero, the open symbols values for the 5 groups fed no food. The predictions are from model 2. 
This model for changes in energy density during starvation has three assumptions. First, assume that during starvation a constant fraction $(s)$ of required energy comes from stored lipid and the rest $(1-s)$ comes from protein. Fish with high lipid levels may initially use predominantly lipid as an energy source during starvation ( $s$ close to 1 ), at least until reserve lipid stores are greatly reduced (Black and Love 1986). Fish with lower levels of lipid use both lipid and protein during starvation (Savitz 1971; Niimi 1972). An equation for estimating $s$ is presented. Second, as in model 2, assume that a negligible amount of water is associated with each gram of lipid and that the amount of water associated with each gram of protein varies with the total amount of protein present in the body. Third, assume that the mass of ash does not change during starvation (Savitz 1971; Niimi 1972) but does increase as fish increase in length (McComish 1974; Barziza and Gatlin 2000). Then, based on the known energy densities of lipid and protein, one can use the energy expenditure during starvation to compute the change in body composition (lipid, protein, water, and ash), energy density, and relative weight.

\section{Model Development}

Let $\Delta E$ be the change in available body energy $(\mathrm{kJ})$ after $1 \mathrm{~d}$ of starvation. This could be computed with a bioenergetics model. During starvation $\Delta E$ will be negative. Fraction $s$ of this energy will come from lipid, and dividing by $D_{f}(\mathrm{~kJ} / \mathrm{g}$ lipid $)$ determines the grams of lipid required to supply that amount of energy. The change in body lipid ( $\Delta F$; g lipid) will be

$$
\Delta F=\left(\frac{s}{D_{f}}\right) \Delta E .
$$

Similarly, the change in body protein $(\Delta P ; \mathrm{g}$ protein $)$ will be

$$
\Delta P=\left(\frac{1-s}{\alpha D_{p}}\right) \Delta E,
$$

where $\alpha$ is the fraction of body protein energy that is available for metabolism $(<1.0$ because of incomplete oxidation).

Because water is so strongly associated with protein, the change in body water $(\Delta H$; g water) can be calculated in equation (26) using the initial level of protein $(P)$, the new level of protein $(\Delta P+P)$, and the regression coefficients determined from equation (25), that is,

$$
\begin{aligned}
\log _{e}(H) & =a_{H}+b_{H} \log _{e}(P) \\
\Delta H & =\exp \left(a_{H}\right)\left[(P+\Delta P)^{b_{H}}-P^{b_{H}}\right] .
\end{aligned}
$$

The change in body weight $(\Delta W)$ will be the sum of these changes (note that $\Delta A=0$ ):

$$
\Delta W=\Delta P+\Delta H+\Delta F .
$$

During starvation all the changes $(\Delta F, \Delta P$, and $\Delta W)$ will be negative. If length, which is presumed to remain constant during starvation (as assumed by Rice et al. 1983), is known, then the change in relative weight can also be determined.

Energy density.-There is a decrease in energy density during starvation because of changes in the amounts of lipid, protein, and water (but not ash). The new energy density $(d)$ is the total energy contained in lipid and protein, divided by body weight, that is,

$$
d=\frac{(F+\Delta F) D_{f}+(P+\Delta P) D_{p}}{(W+\Delta W)} .
$$

Estimating fraction of energy coming from lipid.The fraction of energy coming from lipid when food intake is below maintenance can be estimated from the initial and final estimates of body composition and available energy content during starvation experiments, that is,

$$
s=\frac{\Delta F \cdot D_{f}}{\Delta F \cdot D_{f}+\Delta P \cdot \alpha \cdot D_{p}} .
$$

Note that only a fraction $(\alpha)$ of the energy content of protein is available for fish metabolism during starvation because of incomplete oxidation of the nitrogen products.

\section{Comparison with Data}

Because this model for starvation uses protein to predict water content, one needs regression coefficients from the $\log -\log$ regression of water content on protein content (equation 25). For the common carp data (30 groups; Huisman et al. 1979), $a_{H}=1.711$ (95\% CI: 1.682-1.740), $b_{H}=0.937$ (95\% CI: $\left.0.928-0.947\right)$, and $r^{2}=0.999$. The corresponding regression for the 100 bluegills (McComish 1971) produces the following parameters: $a_{H}=1.477$ (95\% CI: 1.467-1.486), $b_{H}=$ 0.961 (95\% CI: $0.955-0.966)$, and $r^{2}=0.999$.

I used equation (29) to estimate the fraction of energy coming from lipid during starvation for the five starved groups of common carp reported by Huisman et al. (1979), the bluegill experiment of Savitz (1971), and the largemouth bass experiment of Niimi (1972; Table 2). Four of the seven estimated values of $s$ were about 0.6 (range, 0.47-1.0). The highest estimated value, 1.0, was obtained for the largest fish $(586.7 \mathrm{~g}$ initial mean weight). The calculated value for largemouth bass (0.61) agreed with Niimi's (1972) estimate of 0.6 ; he noted that both lipid and protein were used 
TABLE 2.-Changes in wet weight $(W)$, water $(H)$, lipid $(F)$, protein $(P)$, ash $(A)$, and total energy content $(E)$ after a period of starvation (time) at a given temperature $(T)$ in experiments involving common carp (Huisman et al. 1979), bluegill (Savitz 1971), and largemouth bass (Niimi 1972). For common carp, the change in each component was computed from the initial and final wet weights and the reported percent composition value, based on a composite sample of $N$ fish. For bluegills and largemouth bass, $N$ represents the number of fish used to calculate the initial and final means. Parameter $s=\Delta F \cdot D_{f} /\left(\Delta F \cdot D_{f}+\Delta P \cdot \alpha \cdot D_{p}\right)$ represents the change in energy content due to lipid loss divided by the total change in available body energy content.

\begin{tabular}{lccccccccrrrr}
\hline \multicolumn{1}{c}{ Species } & $N$ & Time $(\mathrm{d})$ & $T\left({ }^{\circ} \mathrm{C}\right)$ & $W_{0}(\mathrm{~g})$ & $\Delta W(\mathrm{~g})$ & $\Delta H(\mathrm{~g})$ & $\Delta F(\mathrm{~g})$ & $\Delta P(\mathrm{~g})$ & $\Delta A(\mathrm{~g})$ & $\Delta E(\mathrm{~kJ} / \mathrm{g})$ & $s$ \\
\hline Common carp & 750 & 28 & 27 & 3.32 & -0.77 & -0.55 & -0.07 & -0.15 & 0.02 & -6.67 & 0.47 \\
& 19 & 28 & 23 & 42.1 & -6.0 & -3.0 & -1.84 & -1.15 & 0.10 & -96.47 & 0.75 \\
& 100 & 28 & 27 & 61.3 & -9.8 & -6.54 & -1.42 & -1.63 & -0.11 & -90.68 & 0.62 \\
& 14 & 28 & 27 & 488.6 & -71.2 & -48.75 & -8.40 & -8.62 & -2.64 & -582.27 & 0.65 \\
Bluegill & 15 & 28 & 23 & 586.7 & -40.0 & -34.89 & -7.19 & 0.63 & 2.59 & -313.43 & $1.0^{\mathrm{a}}$ \\
Largemouth bass & $9-10$ & 29 & 23.9 & $67.92^{\mathrm{b}}$ & $-9.94^{\mathrm{b}}$ & $-6.61^{\mathrm{b}}$ & -1.61 & -1.73 & $0.01^{\mathrm{c}}$ & -104.54 & 0.61 \\
& 5 & 40 & 25 & 115 & -16.12 & -10.91 & -2.35 & -2.68 & $-0.07^{\mathrm{d}}$ & -175.69 & 0.61
\end{tabular}

${ }^{a}$ The computed value for $s$ was 1.05 because of the reported small gain (instead of the expected loss) in protein; $s$ is probably very close to its maximum value of 1.0 for this group.

${ }^{\mathrm{b}}$ Only a range of 70-90 g was reported for initial bluegill weight. The initial and final water contents (not reported) were estimated from grams of protein using equation (25) and then used to estimate the initial weight and change in weight and water.

c The values for ash were $4.00 \pm 0.38 \mathrm{~g}$ (95\% confidence interval around the mean) and $4.01 \pm 1.58 \mathrm{~g}$ for the initial and final samples, respectively, so there was no difference in $g$ ash following starvation (Savitz 1971).

${ }^{\mathrm{d}}$ Differences of less than $2 \%$ from the initial 5.86 grams of ash led Niimi (1972) to conclude that there was no change in ash mass during starvation.

for energy during starvation. The same value (0.61) was calculated for the bluegills (Table 2).

Model 3 was used to calculate the changes in body composition and body energy for the 40-d experiment of Niimi (1972). Calculations started with the observed initial mean values of lipid (6.26 g), ash (5.86 g), protein (18.72 g), and water (82.32 g), and calculated total available body energy of $670.5 \mathrm{~kJ}$ with $D_{f}=36.4$ $\mathrm{kJ} / \mathrm{g}$ lipid, $\alpha \cdot D_{p}=20.1 \mathrm{~kJ} / \mathrm{g}$ of protein, and the observed average value of $4.40 \mathrm{~g}$ water per gram protein (equivalent to $a_{H}=\log _{e}(4.40), b_{H}=1.0$ in equations 25 and 26). The stored body energy used by the fish in each 10-d period $(\Delta E)$, which could be estimated with a bioenergetics model, was empirically estimated using the reported composition values for each 10-d period. Given the series of 10-d $\Delta E$ values $(-51.7,-32.9,-28.4$, and $-26.4 \mathrm{~kJ})$, changes in body composition values were then calculated using equation (23) for lipid, equation (24) for protein, and equation (26) for water. The best fit to observed final mean values of lipid, ash, protein, and water were obtained for $s=0.66$; that is, when $66 \%$ of each $10-\mathrm{d}$ change in available body energy came from lipid (Figure 7).

\section{Results and Discussion}

Both lipid level and energy density have strong negative correlations with percent water (Brett et al. 1969; Elliott 1976; Craig 1977; Rottiers and Tucker 1982; Machiels and Henken 1986, 1987; Thompson et al. 1991; Brown and Murphy 1991; Hartman and Brandt 1995; Van Pelt et al. 1997; Pothoven et al. 2006; Wuenschel et al. 2006). These observations are not only for starvation conditions, but also include situations where fish are growing. Model 1 provides an explanation for these relationships in a simple way. When the amount of body water varies in proportion to the amount of protein and lipid (with proportionality constants $y$ and $z$, respectively), then the linear mass balance constraint combines to make body composition a linear function of fraction water (Figure 1). Both fraction lipid and fraction protein will be linear functions of fraction water. Because energy density

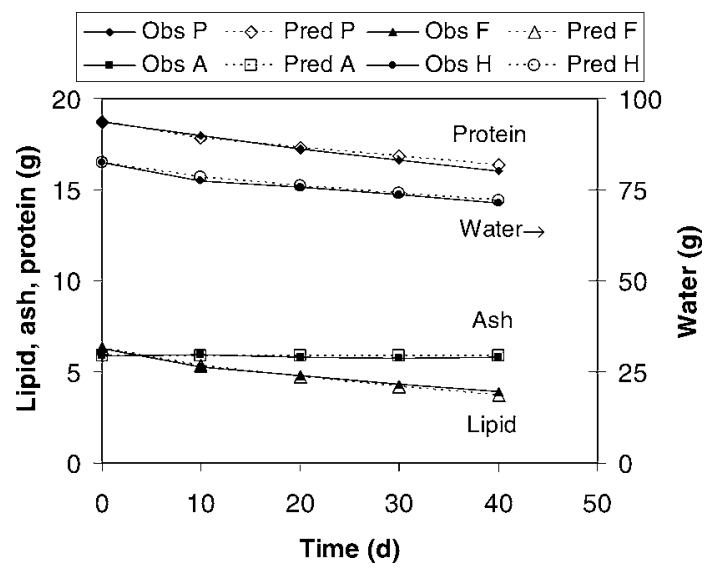

FIGURE 7.-Observed (obs) and predicted (pred) values of lipid $(F)$, ash $(A)$, protein $(P)$, and water $(H)$ during $40 \mathrm{~d}$ of starvation in an experiment with largemouth bass (Niimi 1972). The predictions start with the observed initial mean values $F=6.26 \mathrm{~g}, A=5.86 \mathrm{~g}, P=18.72 \mathrm{~g}$, and $H=82.32 \mathrm{~g}$ as well as a calculated total body energy of $670.50 \mathrm{~kJ}$. The best fits to the observed final mean values were obtained when $66 \%$ of each 10-d change in body energy came from lipid. 
varies in proportion to the fraction protein and lipid (with proportionality constants $D_{p}$ and $D_{f}$, respectively), the linear relationship between body composition and fraction water makes energy density also a linear function of fraction water.

The explanation is similar using model 2 , but more subtle. The very strong relationship between grams of water and grams of protein is not quite linear (at least for common carp and bluegill, where $b_{H}$ is slightly but significantly different from 1.0), and the proportion ash is not constant but increases slightly in larger fish. For fish of similar size, this results in a nearly linear relationship between body composition and fraction water (Figure 4A); for data plotted as fractions of body weight, the expected small deviations from linearity would be difficult to detect unless the measurement errors were unusually small.

Model 2 indicates that body composition can vary with body size (e.g., for common carp and bluegill; Figure 4). A graph of data on fraction lipid, protein, and ash versus fraction water would be expected to show different patterns, depending on the body sizes included. Small individuals are more likely to have high values of fraction water. Hartman and Brandt (1995) observed a nonlinear relationship between energy density and percent dry weight in their compilation of 587 data points from multiple fish taxa, density ranging from about $11 \%$ to $48 \%$ dry weight ( $89 \%$ to $52 \%$ water). This type of nonlinear pattern could be at least partly explained by the inclusion of many sizes of fish in a single analysis. For fish with the same fraction water, smaller individuals would tend to have a lower fraction protein and a higher fraction lipid than larger individuals (Figure 4A).

Model 2 predicts an effect of body weight on energy density, and it appears that this effect is approximately proportional to the logarithm of body weight (Figure 4C). For this reason the logarithm of body weight would be expected to be a significant predictor variable in a multiple regression of energy density on fraction water and $\log (W)$, particularly when there is a large range of body weights in the data set. In addition, including $\log (W)$ as a predictor variable would be expected to result in a steeper negative slope for the effect of fraction water. Regressions were done on several data sets using the following statistical model with and without body weight as a predictor variable:

$$
d=a_{h W}+b_{h W} \cdot h+c_{h W} \cdot \log _{e}(W) .
$$

For the common carp data of Huisman et al. (1979), the average final weights of the fed groups ranged from 5.4 to $953.3 \mathrm{~g}$. A simple regression of $d$ on $h$ resulted in the following coefficients and SEs: $a_{h W}=29.3 \pm 2.1$ $(P<0.001)$ and $b_{h W}=-31.2 \pm 2.7(P<0.001)\left(r^{2}=\right.$
$0.85, N=25$ groups). A multiple regression of $d$ on $h$ and $\log _{e}(W)$ resulted in an increase in the variation explained from $85 \%$ to $97 \%$; all three coefficients were highly significant: $a_{h W}=47.0 \pm 3.3(P<0.001), b_{h W}$ $=-52.4 \pm 4.0(P<0.001)$, and $c_{h W}=-0.418 \pm$ $0.071(P<0.001)\left(R^{2}=0.97, N=25\right.$ groups $) . \mathrm{I}$ calculated energy density for the bluegill data of McComish (1971) using $D_{f}=36.4 \mathrm{~kJ} / \mathrm{g}$ of lipid and $D_{p}$ $=23.6 \mathrm{~kJ} / \mathrm{g}$ of protein. Bluegill weights ranged from 0.47 to $162.70 \mathrm{~g}$. A simple regression of $d$ on $h$ resulted in $a_{h W}=27.9 \pm 1.1(P<0.001)$ and $b_{h W}=-29.8 \pm$ $1.5(P<0.001)\left(r^{2}=0.79, N=100\right)$. A multiple regression of $d$ on $h$ and $\log _{e}(W)$ resulted in an increase in the variation explained from $79 \%$ to $88 \%$; all three coefficients were highly significant: $a_{h W}=35.7 \pm 1.2$ $(P<0.001), b_{h W}=-39.8 \pm 1.6(P<0.001)$, and $c_{h W}$ $=-0.217 \pm 0.025(P<0.001)\left(R^{2}=0.88, N=100\right)$.

For the 184 lake trout and coho salmon samples from Rottiers and Tucker (1982), 171 were 522-5,178 g and only 13 were smaller (25-406 g), so the statistical effect of fish weight would not be expected to be as large. A simple regression of $d$ on $h$ resulted in $a_{h W}=$ $36.6 \pm 0.3(P<0.001)$ and $b_{h W}=-40.9 \pm 0.5(P<$ $0.001)\left(r^{2}=0.978, N=184\right)$. A multiple regression of $d$ on $h$ and $\log _{e}(W)$ resulted in a trivial increase in the variation explained from $97.8 \%$ to $97.9 \%$; however, all three coefficients were highly significant: $a_{h W}=37.8$ $\pm 0.5(P<0.001), b_{h W}=-41.7 \pm 0.5(P<0.001)$, and $c_{h W}=-0.097 \pm 0.033(P<0.01)\left(R^{2}=0.979, N=\right.$ 184). Use of both $h$ and $\log (W)$ as predictor variables should increase the explained variation in $d$ whenever there is substantial variation in body size.

Some of the reported variation in body composition is due to measurement errors; reported percentages do not always sum to exactly 100\% (Niimi 1972; Huisman et al. 1979; Rottiers and Tucker 1982). Regression analyses presented above indicated differences in the parameters of the relationship between water and protein for common carp, bluegills, and largemouth bass. It is not known if these differences are due to actual differences between species or to differences in methods. Recent studies have shown that there can be large differences in the measured values of lipid depending on the methods used (Randall et al. 1991; Iverson et al. 2001).

Body water is regulated to maintain the physiological conditions needed for life's biochemical reactions. This regulation is consistent with the regression analysis presented here showing that the amount of water is strongly related to the amount of protein in healthy fish $\left(r^{2}=0.999\right.$; Figure 3$)$. This regulation may begin to fail in diseased or otherwise stressed fish, in which the stress may invoke a loss of water in marine 
fish and a gain of water (and loss of some ions) in freshwater fish.

The models described here enable simulation of dynamic changes in fish body composition, energy density, and relative weight during starvation. When combined with a model for energy allocation during growth, they will allow bioenergetics models to predict growth in length and weight and the consequent changes in relative weight. This represents a step toward a more mechanistic understanding of changes in relative weight.

Starvation experiments document that fish lose both lipid and water as starvation proceeds; water does not replace lipid (Savitz 1971; Niimi 1972; Huisman et al. 1979; Table 2). In the experiments summarized in Table 2, at least half the loss of weight during starvation was due to loss of water. However, starving fish lose lipid faster than they lose water, so that the relative composition changes; the fraction water increases and the fraction lipid decreases. The models presented here are consistent with these observations.

Relationships between body composition, energy density, and fraction water are used in studies involving microwave fish energy meters (Crossin and Hinch 2005), total body electrical conductivity (TOBEC; Fischer et al. 1996), and body mass impedance devices (Cox and Hartman 2005). With the microwave fish energy meter, microwaves interact with water in fish tissues, and the instrument readings are related to the water content. A microprocessor in the device can be programmed to display estimates of percent lipid, based upon equations determined in laboratory analyses of lipid and water content (Crossin and Hinch 2005); they also found strong relationships $\left(r^{2}=0.94\right)$ between the instrument readings and fish energy density. In the body mass impedance technique (Cox and Hartman 2005), the bioelectrical impedance of the fish's body is used to estimate energy density and body composition. Use of microwave and TOBEC instruments results in a single output value, so items that are estimated must be related to that single measure (Fischer et al. 1996; Crossin and Hinch 2005). Models 1 and 2 indicate that any measure that is correlated with fraction water will also be correlated with fraction lipid, fraction protein, and energy density. The correlations are expected to be linear for fish of similar body weight but may be nonlinear if fish of divergent sizes are examined.

This approach to modeling the changes in body composition permits the modeling of starvation mortality in a more mechanistic way than using relative weight alone (Rice et al. 1983). Field and laboratory studies suggest that the probability of death increases substantially as the amount of reserve lipid declines toward zero (when only structural lipid would remain; e.g., Adams et al. 1985; Sogard and Olla 2000). A simulation model could include such a mechanism, allowing the level of lipid to influence the daily probability of death.

With this approach it would be possible to make simulated fecundity increase with the level of energy reserves. It would also be possible to have the timing of reproduction and the probability of nest abandonment vary with a guarding male's level of energy reserves.

Simulating dynamic changes in the energy density of fish and their prey could be especially important for understanding predator-prey dynamics. Not only does the energy density of prey influence predator growth (Hartman and Brandt 1995; Anthony et al. 2000), but energy stores of the prey can affect vulnerability to predation. Hoey and McCormick (2004) found that juvenile ambon damselfish Pomacentrus amboinensis with lower lipid levels were relatively more vulnerable to piscivores than individuals with higher lipid levels. Fish growth, survival, and reproduction change with energy status, and accounting for the temporal variation in energy status could lead to different predictions about population dynamics than would assuming constant fish condition.

The models presented here distinguish four types of body components: lipid, protein, water, and ash. This approach could be extended to account for different types of lipids, such as structural lipids (e.g., polar phospholipids that are components of cell membranes and the myelin sheath around neurons) and storage lipids (e.g., neutral lipids such as triacylglycerols). Some recent studies have quantified individual fatty acids in fish and found different patterns among species (Iverson et al. 2002).

Using the approach presented here, the coupling of a dynamic model for body composition with fish bioenergetics models would lead to realism for a sensitive component-energy density-and enable additional applications. Experiments are under way to further evaluate the factors that influence energy allocation to growth for length versus growth in energy density and relative weight as fish grow.

\section{Acknowledgments}

This paper is based on a presentation given at the 134th annual meeting of the American Fisheries Society in Madison, Wisconsin. I thank Ed Rutherford, Kevin Wehrly, Tomas Höök, and Zhenming $\mathrm{Su}$ for discussions; Jason Breck for help with data analysis; and three anonymous reviewers for helpful suggestions. D. O'Connor and C. Madenjian (U.S. Geological Survey, Biological Resources Division, Great Lakes Science Center) kindly provided data from the study by 
Rottiers and Tucker (1982). This study was funded by Federal Aid in Sport Fish Restoration (DingellJohnson), Project F-80-R, and the Fish and Game Fund of the State of Michigan.

\section{References}

Adams, S. M., J. E. Breck, and R. B. McLean. 1985. Cumulative stress-induced mortality of gizzard shad in a southeastern U.S. reservoir. Environmental Biology of Fishes 13:103-112.

Anderson, K. P., and E. Ursin. 1977. A multispecies extension to the Beverton and Holt theory, with accounts of phosphorus circulation and primary production. Meddelelser fra Danmarks Fiskeri- og Havundersogelser, N.S. 7:319-435.

Anderson, R. O., and S. J. Gutreuter. 1983. Length, weight, and associated structural indices. Pages 283-300 in L. A. Nielsen and D. L. Johnson, editors. Fisheries techniques. American Fisheries Society, Bethesda, Maryland.

Anthony, J. A., D. D. Roby, and K. R. Turco. 2000. Lipid content and energy density of forage fishes from the northern Gulf of Alaska. Journal of Experimental Marine Biology and Ecology 248:53-78.

Bartell, S. M., J. E. Breck, R. H. Gardner, and A. L. Brenkert. 1986. Individual parameter perturbation and error analysis of fish bioenergetics models. Canadian Journal of Fisheries and Aquatic Sciences 43:160-168.

Barziza, D. E., and D. M. Gatlin III. 2000. An evaluation of total body electrical conductivity to estimate body composition of largemouth bass, Micropterus salmoides. Aquatic Living Resources 13:439-447.

Black, D., and R. M. Love. 1986. The sequential mobilization and restoration of energy reserves in tissues of Atlantic cod during starvation and refeeding. Journal of Comparative Physiology B 156:469-479.

Breck, J. E. 1993. Hurry up and wait: growth of young bluegills in ponds and simulations with an individualbased model. Transactions of the American Fisheries Society $122: 467-480$.

Breck, J. E. 1996. Mechanisms of recruitment failure in bluegill ponds. Michigan Department of Natural Resources, Fisheries Research Report 2024, Ann Arbor.

Brett, J. R. 1995. Energetics. Pages 1-68 in C. Groot, L. Margolis, and W. C. Clarke, editors. Physiological ecology of Pacific salmon. UBC Press, Vancouver.

Brett, J. R., and T. D. D. Groves. 1979. Physiological energetics. Pages 279-352 in W. S. Hoar, D. J. Randall, and J. R. Brett, editors. Fish physiology, volume 8 . Academic Press, New York.

Brett, J. R., J. E. Shelbourn, and C. T. Shoop. 1969. Growth rate and body composition of fingerling sockeye salmon, Oncorhynchus nerka, in relation to temperature and ration size. Journal of the Fisheries Research Board of Canada 26:2363-2394.

Broekhuizen, N., W. S. C. Gurney, A. Jones, and A. D. Bryant. 1994. Modelling compensatory growth. Functional Ecology 8:770-782.

Brown, M. L., and B. R. Murphy. 1991. Relationship of relative weight $\left(W_{r}\right)$ to proximate composition of juvenile striped bass and hybrid striped bass. Transactions of the American Fisheries Society 120:509-518.
Cargnelli, L. M., and M. R. Gross. 1997. Fish energetics: larger individuals emerge from winter in better condition. Transactions of the American Fisheries Society 126:153156.

Cox, M. K., and K. J. Hartman. 2005. Nonlethal estimation of proximate composition in fish. Canadian Journal of Fisheries and Aquatic Sciences 62:269-275.

Craig, J. F. 1977. The body composition of adult perch, Perca fluviatilis, in Windermere, with reference to seasonal changes and reproduction. Journal of Animal Ecology 46:617-632.

Craig, J. F., M. J. Kenley, and J. F. Talling. 1978. Comparative estimations of the energy content of fish tissue from bomb calorimetry, wet oxidation, and proximate analysis. Freshwater Biology 8:585-590.

Crossin, G. T., and S. G. Hinch. 2005. A nonlethal, rapid method for assessing the somatic energy content of migrating adult Pacific salmon. Transactions of the American Fisheries Society 134:184-191.

Danylchuk, A. J., and M. G. Fox. 1994. Age- and sizedependent variation in the seasonal timing and probability of reproduction among mature female pumpkinseed (Lepomis gibbosus). Environmental Biology of Fishes 39:119-127.

Doroshov, S. I. 1985. Biology and culture of sturgeon Acipenseriformes. Pages 251-274 in J. F. Muir and R. J. Roberts, editors. Recent advances in aquaculture. Croom Helm, London.

Dutil, J. D. 1986. Energetic constraints and spawning interval in the anadromous Arctic charr (Salvelinus alpinus). Copeia 1986:945-955.

Elliott, J. M. 1976. Body composition of brown trout (Salmo trutta L.) in relation to temperature and ration size. Journal of Animal Ecology 45:273-289.

Fischer, R. U., J. D. Congdon, and M. Brock. 1996. Total body electrical conductivity (TOBEC): a tool to estimate lean mass and nonpolar lipids of an aquatic organism? Copeia 1996:459-462.

Focken, U., and K. Becker. 1993. Body composition of carp (Cyprinus carpio L.). Pages 269-288 in T. Braunbeck, W. Hanke, and H. Segner, editors. Fish ecotoxicology and ecophysiology. VCH Publishers, New York.

From, J., and G. Rasmussen. 1984. A growth model, gastric evacuation, and body composition in rainbow trout, Salmo gairdneri Richardson, 1836. Dana 3:61-139.

Gerking, S. D. 1955. Influence of rate of feeding on body composition and protein metabolism of bluegill sunfish. Physiological Zoology 28:267-282.

Hartman, K. J., and S. B. Brandt. 1995. Estimating energy density of fish. Transactions of the American Fisheries Society 124:347-355.

Hayes, D. B., and W. W. Taylor. 1994. Changes in the composition of somatic and gonadal tissues of yellow perch following white sucker removal. Transactions of the American Fisheries Society 123:204-216.

Heidinger, R. C., and S. D. Crawford. 1977. Effect of temperature and feeding rate on the liver-somatic index of the largemouth bass, Micropterus salmoides. Journal of the Fisheries Research Board of Canada 34:633-638.

Henderson, M. A., and F. J. Ward. 1978. Changes in the chemical composition, calorific and water content of yellow perch fry, Perca fluviatilis flavescens. Internatio- 
nale Vereinigung für Theoretische und Angewandte Limnologie Verhandlungen 20:2025-2030.

Hewett, S. W., and B. L. Johnson. 1992. Fish Bioenergetics Model 2. University of Wisconsin Sea Grant Institute, Technical Report WIS-SG-92-250, Madison.

Hoey, A. S., and M. I. McCormick. 2004. Selective predation for low body condition at the larval-juvenile transition of a coral reef fish. Oecologia 139:23-29.

Huisman, E. A., J. G. P. Breteler, M. M. Vismans, and E. Kanis. 1979. Retention of energy, protein, fat, and ash in growing carp (Cyprinus carpio L.) under different feeding and temperature regimes. Pages 175-188 in J. E. Halvers and K. Tiews, editors. Finfish nutrition and fish feed technology, volume I. Heeneman, Berlin.

Iverson, S. J., K. J. Frost, and S. L. C. Lang. 2002. Fat content and fatty acid composition of forage fish and invertebrates in Prince William Sound, Alaska: factors contributing to among- and within-species variability. Marine Ecology Progress Series 241:161-181.

Iverson, S. J., S. L. C. Lang, and M. H. Cooper. 2001. Comparison of the Bligh and Dyer and Folch methods for total lipid determination in a broad range of marine tissue. Lipids 36:1283-1287.

Jobling, M. 1994. Fish bioenergetics. Chapman and Hall, London.

Jonas, J. L., C. E. Kraft, and T. L. Margenau. 1996. Assessment of seasonal changes in energy density and condition in age- 0 and age- 1 muskellunge. Transactions of the American Fisheries Society 125:203-210.

Kitchell, J. F., D. J. Stewart, and D. Weininger. 1977. Applications of a bioenergetics model for yellow perch (Perca flavescens) and walleye (Stizostedion vitreum vitreum). Journal of the Fisheries Research Board of Canada 34:1922-1935.

Lam, T. J. 1983. Environmental influences on gonadal activity in fish. Pages 65-116 in W. S. Hoar, D. J. Randall, and E. M. Donaldson, editors. Fish physiology, volume 9. Reproduction, part B. Behavior and fertility control. Academic Press, New York.

Liao, H., C. L. Pierce, D. H. Wahl, J. B. Rasmussen, and W. C. Leggett. 1995. Relative weight $\left(W_{r}\right)$ as a field assessment tool: relationships with growth, prey biomass, and environmental conditions. Transactions of the American Fisheries Society 124:387-400.

Love, R. M. 1970. The chemical biology of fishes. Academic Press, New York.

Machiels, M. A. M., and A. M. Henken. 1986. A dynamic simulation model for growth of the African catfish, Clarias gariepinus (Burchell 1822), I. Effect of feeding level on growth and energy metabolism. Aquaculture 56:29-52.

Machiels, M. A. M., and A. M. Henken. 1987. A dynamic simulation model for growth of the African catfish, Clarias gariepinus (Burchell 1822), II. Effect of feed composition on growth and energy metabolism. Aquaculture 60:33-53.

McComish, T. S. 1971. Laboratory experiments on growth and food conversion by the bluegill. Doctoral dissertation. University of Missouri, Columbia.

McComish, T. S. 1974. Estimation of bluegill (Lepomis macrochirus) proximate composition with regression models. Journal of the Fisheries Research Board of Canada 31:1250-1254.

Murphy, B. R., D. W. Willis, and T. A. Springer. 1991. The relative weight index in fisheries management: status and needs. Fisheries 16(2):30-38.

Newburgh, L. H., M. W. Johnston, and J. D. Newburgh. 1945. Some fundamental principles of metabolism. Edward Brothers, Ann Arbor, Michigan.

Niimi, A. 1972. Changes in the proximate body composition of largemouth bass (Micropterus salmoides) with starvation. Canadian Journal of Zoology 50:815-819.

Niimi, A. 1974. Relationship between ash content and body weight in lamprey (Petromyzon marinus), trout (Salmo gairdneri), and bass (Micropterus salmoides). Copeia 1974:794-795.

Niimi, A. J., and F. W. H. Beamish. 1974. Bioenergetics and growth of largemouth bass (Micropterus salmoides) in relation to body weight and temperature. Canadian Journal of Zoology 52:447-456.

Oliver, J. D., G. F. Holeton, and K. E. Chua. 1979. Overwinter mortality of fingerling smallmouth bass in relation to size, relative energy stores, and environmental temperature. Transactions of the American Fisheries Society 108:130-136.

Peters, R. H. 1983. The ecological implications of body size. Cambridge University Press, Cambridge, UK.

Pothoven, S. A., T. F. Nalepa, C. P. Madenjian, R. R. Rediske, P. J. Schneeberger, and J. X. He. 2006. Energy density of lake whitefish Coregonus clupeaformis in Lakes Huron and Michigan. Environmental Biology of Fishes 76:151158.

Randall, R. C., H. Lee II, R. J. Ozretich, J. L. Lake, and R. J. Pruell. 1991. Evaluation of selected lipid methods for normalizing pollutant bioaccumulation. Environmental Toxicology and Chemistry 10:1431-1436.

Rice, J. A., J. E. Breck, S. M. Bartell, and J. F. Kitchell. 1983. Evaluating the constraints of temperature, activity, and consumption on growth of largemouth bass. Environmental Biology of Fishes 9:263-275.

Ridgway, M. S., B. J. Shuter, and E. E. Post. 1991. The relative influence of body size and territorial behaviour on nesting asynchrony in male smallmouth bass, Micropterus dolomieui (Pisces: Centrarchidae). Journal of Animal Ecology 60:665-681.

Rose, K. A., E. S. Rutherford, D. S. McDermot, J. L. Forney, and E. L. Mills. 1999. Individual-based model of yellow perch and walleye populations in Oneida Lake. Ecological Monographs 69:127-154.

Rottiers, D. V., and R. M. Tucker. 1982. Proximate composition and caloric content of eight Lake Michigan fishes. U.S. Fish and Wildlife Service Technical Paper 108.

Savitz, J. 1971. Effects of starvation on body protein utilization of bluegill (Lepomis macrochirus Rafinesque) with a calculation of caloric requirements. Transactions of the American Fisheries Society 100:18-21.

Schmidt-Nielsen, K. 1975. Animal physiology: adaptation and environment. Cambridge University Press, London.

Shuter, B. J., J. A. MacLean, F. E. J. Fry, and H. A. Regier. 1980. Stochastic simulation of temperature effects on first-year survival of smallmouth bass. Transactions of the American Fisheries Society 109:1-34. 
Simpkins, D. G., W. A. Hubert, C. Martinez del Rio, and D. C. Rule. 2003. Effect of swimming activity on relative weight and body composition of juvenile rainbow trout. North American Journal of Fisheries Management 23:283-289.

Sogard, S. M., and B. L. Olla. 2000. Endurance of simulated winter conditions by age-0 walleye pollock: effects of body size, water temperature, and energy stores. Journal of Fish Biology 56:1-21.

Stewart, D. J., and M. Ibarra. 1991. Predation and production by salmonine fishes in Lake Michigan, 1978-1988. Canadian Journal of Fisheries and Aquatic Sciences 48:909-922.

Stewart, D. J., D. Weininger, D. V. Rottiers, and T. A. Edsall. 1983. An energetics model for lake trout, Salvelinus namaycush: application to the Lake Michigan population. Canadian Journal of Fisheries and Aquatic Sciences 40:681-698.

Tarby, M. J. 1977. Energetics and growth of walleye (Stizostedion vitreum vitreum) in Oneida Lake, New York. Doctoral dissertation. Cornell University, Ithaca, New York

Thompson, J. M., E. P. Bergersen, C. A. Carlson, and L. R. Kaeding. 1991. Role of size, condition, and lipid content in the overwinter survival of age-0 Colorado squawfish. Transactions of the American Fisheries Society 120:346353

Tyler, A. V., and R. S. Dunn. 1976. Ration, growth, and measures of somatic and organ condition in relation to meal frequency in winter flounder, Pseudopleuronectes americanus, with hypotheses regarding population ho- meostasis. Journal of the Fisheries Research Board of Canada 33:63-75.

Van Pelt, T. I., J. F. Piatt, B. K. Lance, and D. D. Roby. 1997. Proximate composition and energy density of some North Pacific forage fishes. Comparative Biochemistry and Physiology 118A:1393-1398.

Van Winkle, W., B. J. Shuter, B. D. Holcomb, H. I. Jager, J. A. Tyler, and S. Y. Whitaker. 1997. Regulation of energy acquisition and allocation to respiration, growth, and reproduction: simulation model and example using rainbow trout. Pages 103-137 in R. C. Chambers and E. A. Trippel, editors. Early life history and recruitment in fish populations. Chapman and Hall, London.

Weatherley, A. H., and H. S. Gill. 1983. Protein, lipid, water, and caloric contents of immature rainbow trout, Salmo gairdneri Richardson, growing at different rates. Journal of Fish Biology 23:653-673.

Wege, G. J., and R. O. Anderson. 1978. Relative weight $\left(W_{r}\right)$ : a new index of condition for largemouth bass. Pages 79 91 in G. Novinger and J. Dillard, editors. New approaches to the management of small impoundments. American Fisheries Society, North Central Division, Special Publication 5, Bethesda, Maryland.

Willis, D. W., C. S. Guy, and B. R. Murphy. 1991. Development and evaluation of a standard weight $\left(W_{s}\right)$ equation for yellow perch. North American Journal of Fisheries Management 11:374-380.

Wuenschel, M. J., A. R. Jugovich, and J. A. Hare. 2006. Estimating the energy density of fish: the importance of ontogeny. Transactions of the American Fisheries Society 135:379-385. 